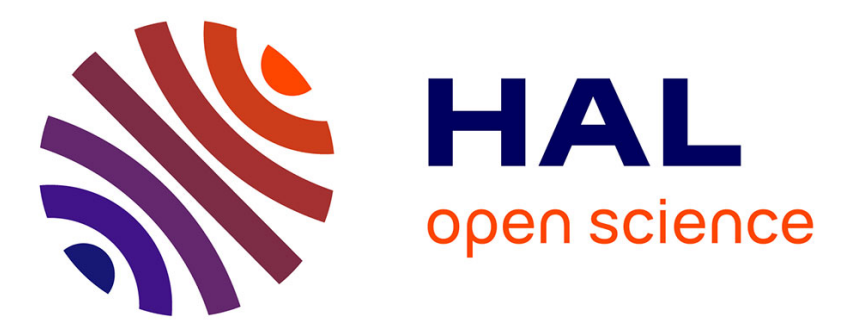

\title{
Transketolase and fructose-1,6-bis-phosphate aldolase, complementary tools for access to new ulosonic acid analogues
}

\author{
Dominique Crestia, Colette Demuynck, Jean Bolte
}

\section{To cite this version:}

Dominique Crestia, Colette Demuynck, Jean Bolte. Transketolase and fructose-1,6-bis-phosphate aldolase, complementary tools for access to new ulosonic acid analogues. Tetrahedron, 2004, 60, pp.2417-2425. 10.1016/j.tet.2003.12.069 . hal-00135919

\section{HAL Id: hal-00135919 https://hal.science/hal-00135919}

Submitted on 9 Mar 2007

HAL is a multi-disciplinary open access archive for the deposit and dissemination of scientific research documents, whether they are published or not. The documents may come from teaching and research institutions in France or abroad, or from public or private research centers.
L'archive ouverte pluridisciplinaire HAL, est destinée au dépôt et à la diffusion de documents scientifiques de niveau recherche, publiés ou non, émanant des établissements d'enseignement et de recherche français ou étrangers, des laboratoires publics ou privés. 


\title{
Transketolase and fructose-1,6-bis-phosphate aldolase, complementary tools for access to new ulosonic acid analogues
}

\author{
Dominique Crestia, Colette Demuynck and Jean Bolte* \\ Laboratoire de Synthèse et Etude de Systèmes à Intérêt Biologique, UMR 6504 du CNRS, Université Blaise Pascal, \\ 63177 Aubière Cedex, France
}

\begin{abstract}
A new approach to the synthesis of ulosonic acids KDO and DAH is described. The key step is the $\mathrm{C}_{5}-\mathrm{C}_{6}$ bond formation catalysed by fructose-1,6-bisphosphate aldolase (for KDO) or transketolase (for DAH) using substituted acrylonitrile $\alpha$-hydroxyaldehyde. All asymmetric carbon configurations are determined in an enzymatic step by the means of deshydrogenase or lipase. This strategy, using a non-metabolism pathway, allows access to novel precursors of KDO, DAH and analogues.
\end{abstract}

\section{Introduction}

3-Deoxy-2-ulosonic acids are known as a variety of important natural products including sialic acids $(\mathrm{N}$-acetylneuraminic acid and its derivatives), 3-deoxy-D-arabino-2heptulosonic acid 7-phosphate (DAH-7-P), 3-deoxy-Dmanno-2-octulosonic acid (KDO), and 3-deoxy-D-glyceroD-galacto-2-nonulosonic acid (KDN). In the course of our studies, we were especially interested in close analogues of $\mathrm{KDO}$ and DAH. KDO is an integral component of the lipopolysaccharides of Gram-negative bacteria. New syntheses of KDO may be useful in developing analogues capable of disrupting the biosynthesis of bacterial cell-wall components, and thereby lead to new antibacterial agents. ${ }^{1}$ DAH-7-P is an important intermediate in the shikimic acid pathway along which the aromatic amino acids are biosynthesised in bacteria, fungi and plants. Disruption of aromatic amino acid biosynthesis (in plants) is purported to be an extremely effective vehicle for herbicide action. ${ }^{1,2}$ This specific occurrence of DAH-7-P makes its biosynthetic pathway a possible target. Some analogues have been tested as herbicide agents. ${ }^{3}$ For these reasons, syntheses of KDO, DAH and analogues have remained the subject of investigation over the last few years. Total syntheses of these rare carbohydrates have been based on readily accessible sugar precursors. ${ }^{4}$ Most enzymatic approaches involve specific aldol condensation of pyruvate or phosphoenolpyruvate (PEP) with aldoses catalysed by the appro-

Keywords: C-C bond; Aldolase; Transketolase; KDO; DAH; Polyol dehydrogenase.

* Corresponding author. Tel.: +33-4-73-40-71-28; fax: +33-4-73-40-77-

17; e-mail address: jbolte@chimie.univ-bpclermont.fr priate aldolase or synthetase. ${ }^{5}$ In all cases, the $\mathrm{C}_{3}-\mathrm{C}_{4}$ bond is created with control of configuration in $\mathrm{C}_{4}$ (Scheme 1).

Although these methods can afford KDO and DAH in moderate to good yields, they do not allow synthesis of all analogues due to the specificity of the enzymes for pyruvate, PEP and close analogues of D-arabinose.

We looked for a more versatile approach using enzymes not involved in the biosynthetic pathway of both targeted ulosonic acids. Our strategy was based on the formation of the $\mathrm{C}_{5}-\mathrm{C}_{6}$ bonds using fructose-1,6-bis-phosphate aldolase from rabbit muscle (RAMA) or yeast transketolase (TK). The utility of these enzymes in organic syntheses is well known $^{6}$ for the synthesis of monosaccharide analogues.

Our retrosynthetic strategy is shown in Scheme 2. For KDO, the key step would be the condensation of dihydroxyacetone phosphate (DHAP) onto aldehyde A catalysed by aldolase (RAMA). In the same way, the transfer of a hydroxyacetyl group from hydroxypyruvic acid (HPA) onto aldehyde $\mathbf{A}$, catalysed by transketolase (TK) would afford a precursor of 3-deoxy-D-arabino-2-heptulosonic acid (DAH). In these reactions, both enzymes catalyse the $\mathrm{C}_{5}-\mathrm{C}_{6}$ bond formation and determine the stereochemistry of these centres in the configuration present in $\mathrm{KDO}\left(\mathrm{C}_{5}, \mathrm{C}_{6}\right)$ and $\mathrm{DAH}\left(\mathrm{C}_{5}\right)$, according to Scheme 2. The configuration at $\mathrm{C}_{6}(\mathrm{DAH})$ or $\mathrm{C}_{7}(\mathrm{KDO})$ would be obtained by chemical or enzymatic stereospecific reduction of the keto group. The acryloyl pattern in $\mathbf{A}$ is a good precursor for the pyruvyl moiety of 3-deoxy-2-ulosonic acids, and numerous syntheses of 3-deoxy-D-manno-2-octulosonic acid (KDO) or sialic acids are based on the reaction of ethyl bromomethacrylate with aldehyde to introduce this function. ${ }^{7}$ The use of a 


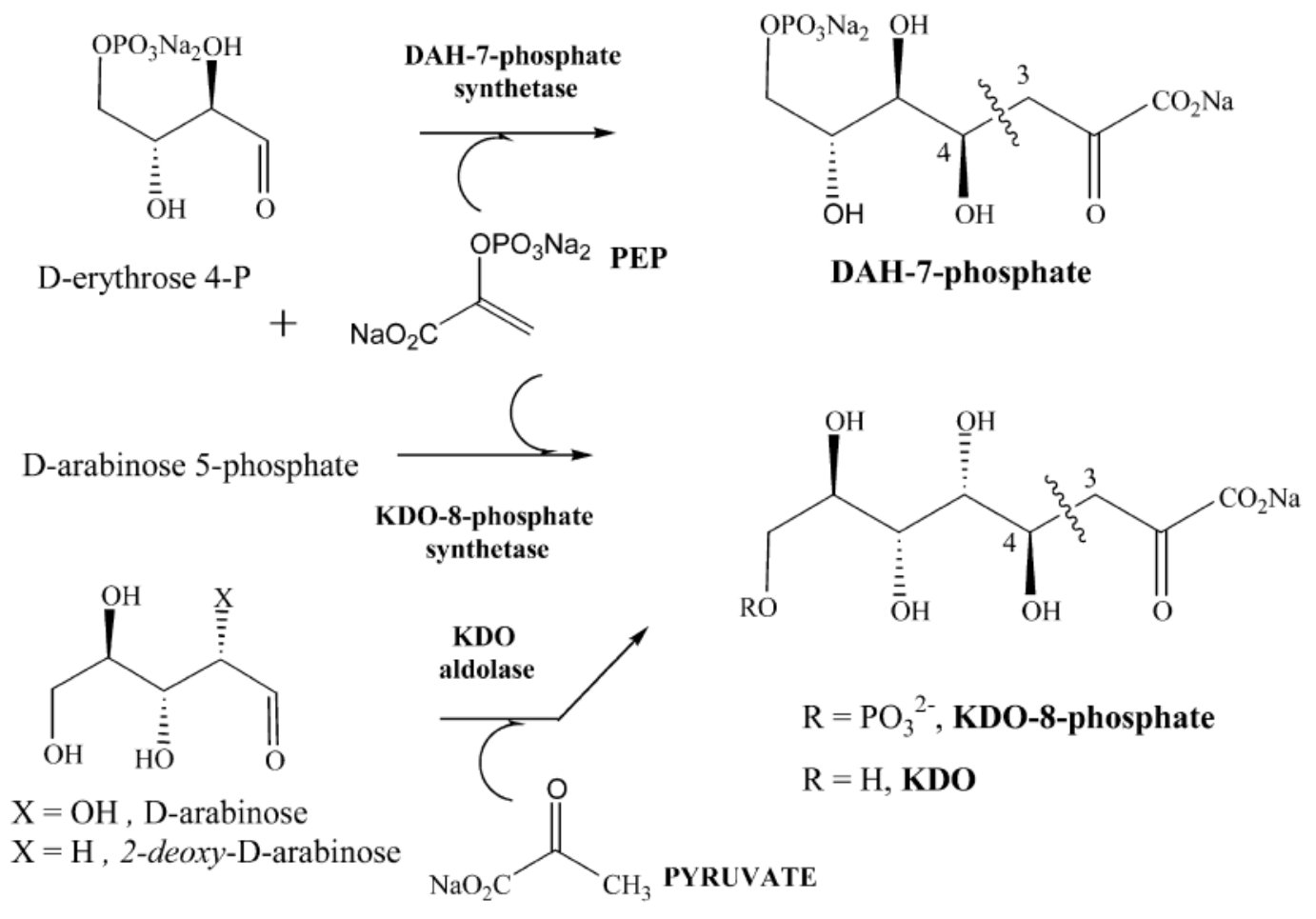

Scheme 1 .

methylidene group as a precursor of the ketone also offers the advantage of simplifying the identification of the various intermediate products by limiting the number of cyclic hemiacetal forms.

This strategy could also lead to analogues of ulosonic acids. For example, using the enantiomer of $\mathbf{A}$ in aldolase catalysed synthesis would provide the $\mathrm{C}_{4}$ epimer of KDO. Also, the 4-deoxy analogues of $\mathbf{A}$ are substrates of aldolase, as was demonstrated in a preliminary report ${ }^{8}$ and would lead to 4-deoxy KDO. Moreover, during the reduction of $\mathrm{C}_{6}$ or $\mathrm{C}_{7}$ keto group, compounds of the $\mathrm{L}$ series can be obtained.

In this paper, we report the activity of the RAMA and TK towards two precursors of aldehyde $\mathbf{A}$, and the syntheses of various KDO and DAH analogues.

\section{Results and discussion}

\subsection{Preparation of $\alpha$-hydroxyaldehydes substrates}

In a previous paper, ${ }^{9}$ we described the synthesis of synthons $\mathbf{1}$ and $\mathbf{2}$ in an enantiomerically pure form by enzymatic resolution with Candida rugosa lipase, or by microbial reduction of the corresponding ketones using Aspergillus niger and Lactobacillus kefir.

$(+)-\mathbf{1}$ and (-)-1 were hydrolysed in the presence of Dowex $\mathrm{H}^{+}$resin (Scheme 3). No racemisation occurred during the hydrolysis as indicated by the specific rotation of the resulting aldehydes (+)-3 and (-)-3. In contrast, usual acidic conditions for the acetal hydrolysis of $\mathbf{2}$ led to racemic $( \pm)-4$. Moreover, we observed the formation of $\alpha$-hydroxyketone which implies an enediol intermediate. It<smiles>O=C(O)C[C@@H](O)[C@H](O)[C@H](O)[C@H](O)CO</smiles>

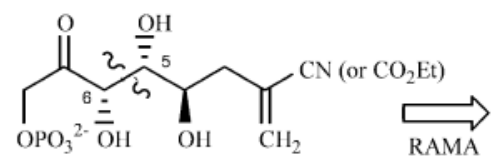<smiles></smiles>

KDO<smiles>O=C(O)C[C@@H](O)[C@H](O)[C@H](O)CO</smiles><smiles>C=C</smiles><smiles>C=C(CNC(=O)OCc1ccccc1)C[C@H](O)[C@H](O)C(=O)CO</smiles><smiles>O=C(O)CO</smiles><smiles>C=C(C#CC(=O)OC)C[C@@H](O)C=O</smiles>

A 
<smiles>C=C(C#N)CC(O)C(OC)OC</smiles><smiles>C=C(CC(O)C(=O)[I-]C)C(=O)CC(O)C(OC)OC</smiles>

Scheme 3 .

can be supposed that the presence of the ester group catalyses this isomerisation. To avoid this racemisation, we tried a deprotection method under non-acidic conditions: the deprotection of aldehyde $( \pm)-2$ was carried out by reaction with $\mathrm{LiBF}_{4}$ in acetonitrile with $34 \%$ yield. ${ }^{10}$ This yield was too low for the method to be considered useful for the deprotection of the optically pure (+)-4 and (-)-4. Racemic 4 and/or optically pure obtained aldehydes 3 were submitted to the action of aldolase and transketolase.

\subsection{Syntheses with RAMA}

Aldehydes $( \pm)-\mathbf{3},(+)-(R)-\mathbf{3},(-)-(S)-\mathbf{3}$ and $( \pm)-\mathbf{4}$ were assayed as substrates for aldolase. The reaction was monitored by enzymatic titration of residual DHAP (DHAP was prepared and assayed according to Gefflaut et al. ${ }^{11}$ ) and the characteristic constants of the reaction, the apparent Michaëlis constant $K_{\mathrm{m}}$ and the maximum rate $V_{\max }$ were calculated. The $V_{\max }$ values are given in percent of the activity of RAMA with the natural substrate, D-glyceraldehyde-3-P. The results are reported in Table 1.

Table 1. Kinetic constants for the reactions of hydroxyaldehydes 3 and 4 catalysed by aldolase (RAMA) and transketolase (TK)

\begin{tabular}{lcccccc}
\hline Enzyme & \multicolumn{2}{c}{ Aldolase (RAMA) } & & \multicolumn{2}{c}{ Transketolase } \\
\cline { 2 - 3 } \cline { 6 - 7 } Substrate & $V_{\max }(\%)$ & $K_{\mathrm{m}}(\mathrm{mM})$ & & $V_{\max }(\%)$ & $K_{\mathrm{m}}(\mathrm{mM})$ \\
\hline$(-)-1 \rightarrow(-)-3$ & 22 & 66 & & 1 & 273 \\
$(+)-\mathbf{1} \rightarrow(+)-3$ & 34 & 48 & & 31 & 9 \\
$( \pm)-1 \rightarrow( \pm)-3$ & 27 & 57 & & 45 & 72 \\
$( \pm)-\mathbf{2} \rightarrow( \pm)-4$ & 21 & 53 & & 0 & - \\
\hline
\end{tabular}

All tested aldehydes are substrates for RAMA. It appears that racemic aldehydes $( \pm)-\mathbf{3}$ and its enantiomers have no difference in activity towards RAMA. This result confirms that RAMA is not enantioselective toward these unphosphorylated $\alpha$-hydroxyaldehydes.

2.2.1. Syntheses from aldehyde 3 . We have performed the enzymatic syntheses with each enantiomer of $( \pm)-3$ (Scheme 3). The reaction was carried out on $5 \mathrm{mmol}$ of DHAP and an excess of aldehyde in the presence of RAMA (Scheme 4). The progress of the reaction was followed by enzymatic assay of DHAP in the mixture. After $45 \mathrm{~h}$, no more DHAP was present in the solution. The phosphate group was hydrolysed at $\mathrm{pH} 4$ in the presence of phytase acid from Aspergillus ficuum. After only one purification on silica gel, the expected octuloses $\mathbf{5 a}$ and $\mathbf{5 b}$ were obtained with 75 and $72 \%$ yield, respectively, from $(R)-(+)-3$ and $(S)-(-)-3$. They were easily characterized by ${ }^{13} \mathrm{C}$ NMR spectroscopy as well as mass spectroscopy. Compounds 5a and $\mathbf{5 b}$ exist in both $\alpha$ and $\beta$ hemiacetalic forms. On the basis of quantitative ${ }^{13} \mathrm{C}$ NMR experiments, we have attributed their proportions as $\alpha 90 \% / \beta 10 \%$. Analysis of $400 \mathrm{MHz}{ }^{1} \mathrm{H}$ NMR spectrum of $\mathbf{5 b}$ established the stereochemistry of the aldol adduct. As expected, the threo stereochemistry was obtained during reactions of RAMA with sugar phosphates as indicated by the small coupling constant between the $\mathrm{C}(3)$ and $\mathrm{C}(4)$ protons $(2.9 \mathrm{~Hz})$. This implies a trans-diequatorial arrangement of these protons. A range of other examples supports this conclusion. $^{12}$

We also investigated the enzymatic reactions in preparative scale starting from racemic aldehyde ( \pm )3. The two diastereomers $\mathbf{5 a}$ and $\mathbf{5 b}$ were obtained in equivalent quantity with a overall yield of $60 \%$, but the purification has been difficult because two successive separations on silica gel have been necessary to purify them.

2.2.2. Synthesis from aldehyde 4. Using the same procedure, we have carried out the enzymatic reaction on a preparative scale starting from the racemic aldehyde $( \pm)-4$ (Scheme 4). The two diastereomers 6a and $\mathbf{6 b}$ were obtained in equivalent quantity with an overall yield of $11 \%$. Due to

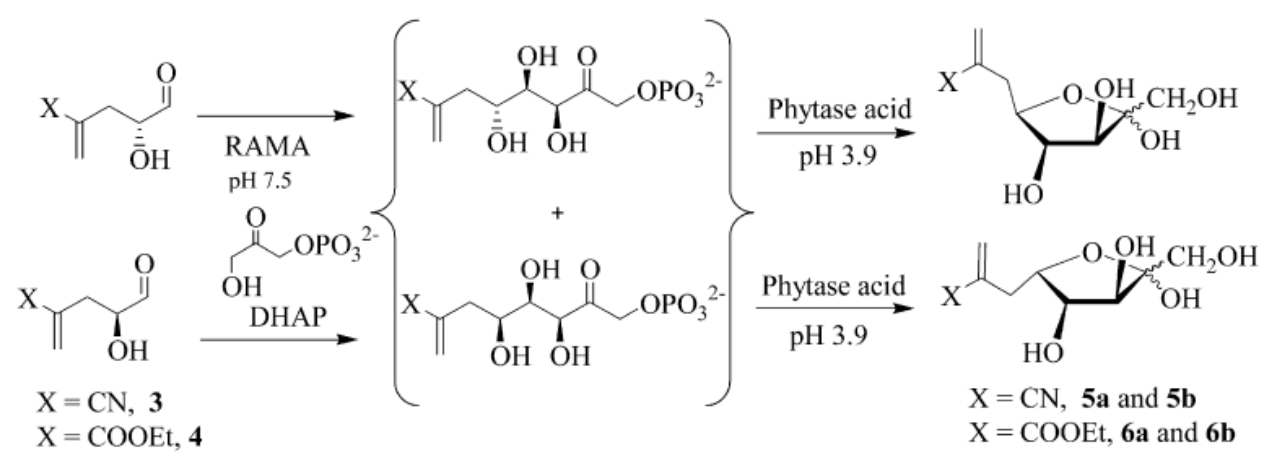

Scheme 4 . 
<smiles>C=C(C#N)CC(O)C=O</smiles>

$(+/-)-3$

$(+)-3$<smiles>O=C(O)C(=O)O</smiles>

1/2 HPA

HPA
TK

$\overrightarrow{\mathrm{PH}} 7.5 \mathrm{MgCl} \mathrm{T}_{2}$

$\mathrm{CO}_{2}$

Scheme 5 ,

this low yield and the difficult separation of $\mathbf{6 a}$ and $\mathbf{6 b}$, this method was not pursued further.

\subsection{Synthesis with TK}

Compounds $\mathbf{3}$ and $\mathbf{4}$ were tested as substrates of TK. The results are reported in Table 1 . Unlike most $\alpha$-hydroxyaldehydes, the ester $( \pm)-\mathbf{4}$ was not a substrate for TK. However, the nitrile $(R)-(+)-\mathbf{3}$ displays a remarkable reactivity with a low $K_{\mathrm{m}}$ value of $9 \mathrm{mM}$. As expected, the $(S)-(-)-\mathbf{3}$ is not a substrate. The low reactivity was probably due to the presence of trace amount of the $R$ enantiomer. These results allowed us to attribute the absolute configuration of $(-)-\mathbf{3}$ and $(+)-\mathbf{3}$ in our previous ( \pm )-3 enzymatic resolution study. ${ }^{9}$ The $K_{\mathrm{m}}$ value of racemic $( \pm)-\mathbf{3}$ is higher than the supposed value of about $18 \mathrm{mM}$. The enantiomer $(S)-(-)-3$ could inhibit the enzyme and thus explains such a difference.

Since TK exhibits a high enantioselectivity towards racemic $\alpha$-hydroxyaldehydes, in spite of the higher $K_{\mathrm{m}}$ value, the synthesis could be carried out from racemic $( \pm)-\mathbf{3}$ or from the $R$ enantiomer.

2.3.1. Synthesis from aldehyde ( \pm )-3. Racemic $\alpha$-hydroxyaldehyde ( \pm )-3 and one half equivalent of $\beta$-hydroxypyruvic acid (HPA) were reacted in the presence of the TK from $S$. cerevisiae and their required cofactors (thiamine pyrophosphate TPP and magnesium) (Scheme 5). The experiment was performed on a $5 \mathrm{mmol}$ scale of the acceptor substrate in TRIS buffer at $\mathrm{pH} 7.5$. Progress of the reaction was monitored by thin-layer chromatography (silica gel, 10\% methanol in dichloromethane) and by enzymatic assay of HPA in the mixture. After $14 \mathrm{~h}$, no more HPA was present in the solution. The heptulose 7 was obtained after silica gel chromatography with a yield of $38 \%$. The heptulose 7 was easily characterised by ${ }^{13} \mathrm{C}$ NMR spectroscopy since all signals were assigned: $J \bmod$ experiment confirmed that only one diastereomer had been formed. This allowed us to assign the $\mathrm{C}_{6}$ carbon of the carbonyl group and the $\mathrm{C}_{2}$ carbon of the hydroxymethyl group, respectively, near 213 and $68 \mathrm{ppm}$. CI mass spectroscopy results were also consistent with the proposed structure with a signal at $186\left(\mathrm{M}+\mathrm{H}^{+}\right)$for ketose 7 .

The residual aldehyde $(S)-(-)-3$ was isolated in $43 \%$ yield. Nevertheless, the separation of the heptulose 7 and unreacted aldehyde $(S)-(-)-\mathbf{3}$ has been difficult. Due to this, we investigated an enzymatic synthesis catalysed by TK from aldehyde $(R)-(+)-\mathbf{3}$.

2.3.2. Synthesis from aldehyde (+)- $\boldsymbol{R}-\mathbf{3}$. Using the same procedure, we have carried out the enzymatic reaction on

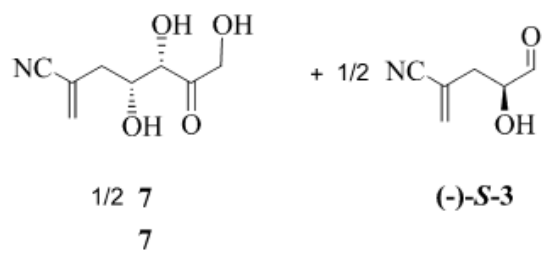

preparative scale starting from the optically pure aldehyde $(R)-(+)-\mathbf{3}$ with an excess of HPA. HPA was completely consumed in $14 \mathrm{~h}$. The heptulose 7 was obtained with a yield of $73 \%$ (Scheme 5). This was better than with the racemic acceptor substrate $( \pm)-\mathbf{3}$ which is consistent with kinetic studies.

\subsection{Reduction of the carbonyl group}

The synthesis of the keto acids first requires the reduction of the carbonyl group of both octuloses $\mathbf{5 a}$ and $\mathbf{5} \mathbf{b}$ and the heptulose 7. In spite of our efforts, all the tested chemical methods have resulted in the reduction of the carboncarbon double bond.

To solve this problem, reduction of the carbonyl using isolated enzyme or microorganisms was investigated.

2.4.1. Reduction of carbonyl group with purified enzyme. For each RAMA and TK adducts, respectively, 5a, 5b and 7, enzymatic reduction was performed at $\mathrm{pH} 7$. This utilised available iditol dehydrogenase (IDH) from Candida utilis coupled with the formate dehydrogenase (FDH), and sodium formate to regenerate the NADH in situ (Scheme 6). Progress of the reaction was monitored by thin-layer chromatography (silica gel, $10 \%$ methanol in dichloromethane). Due to the diastereostelectivity of the reaction catalysed by $\mathrm{IDH},{ }^{13}$ the newly created asymmetric centres in $\mathrm{C}_{6}$ or $\mathrm{C}_{7}$ are of the $S$ configuration. Three compounds $\mathbf{8 a}$, $\mathbf{8 b}$ and 9 were obtained in yields from 66 to $69 \%$. They were easily characterised by ${ }^{13} \mathrm{C}$ NMR spectroscopy since all signals were assigned: $J$ mod experiments confirmed that only one diastereomer has been formed in each reduction. There are no reported enzymes which form the opposite $R$ enantiomer in $\mathrm{C}_{6}$ or $\mathrm{C}_{7}$. Therefore, whole cell microorganisms were tested for this activity (Scheme 6).

2.4.2. Reduction of carbonyl group with microorganisms. Compounds $\mathbf{5 a}, \mathbf{5 b}$ and $\mathbf{7}$ were submitted to the action of baker's yeast, using commercial freeze-dried cells under non-fermenting conditions. In each case, only one compound according to $J$ mod NMR spectrum has been obtained with a modest yield $(25-30 \%)$. We assigned the structures $\mathbf{8 a}, \mathbf{8 b}$ and $\mathbf{9}$ to these reduction products on the basis of their NMR spectra. This conclusion was confirmed by the optical values. In this reduction, enzyme acting in baker's yeast possesses the same stereostelectivity as IDH leading to saccharides in the $\mathrm{S}$ series. For large-scale synthesis, the less expensive baker's yeast method would be preferred. However, the biotransformations performed in the presence of washed resting cells of Aspergillus niger appeared to be less stereoselective because we obtained a mixture of two 


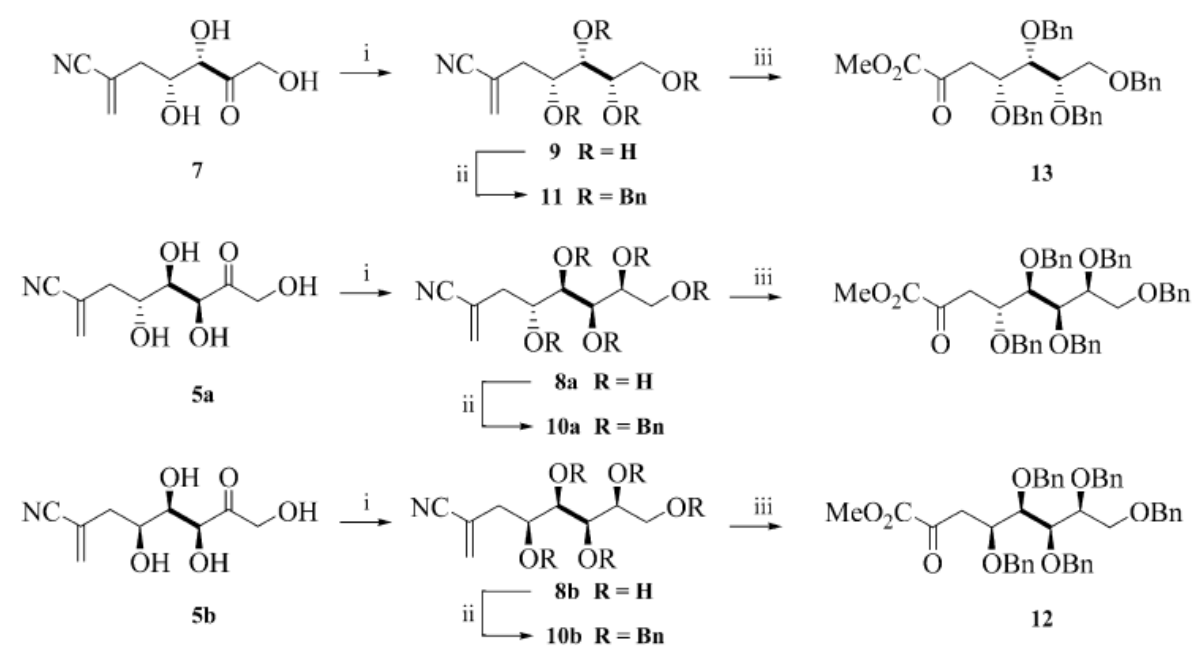

Scheme 6. Key: (i) IDH (EC 1.1.1.14), $\mathrm{FDH}\left(\mathrm{EC} 1.1 .1 .14\right.$ ), $\mathrm{NADH}, \mathrm{HCO}_{2} \mathrm{Na}$; (ii) $\mathrm{NaH}, \mathrm{BrBn}, \mathrm{IN}(\mathrm{Bu})_{4}$; (iii) $1 . \mathrm{NaOH}, 110^{\circ} \mathrm{C}, 9$ days, $2 . \mathrm{MeI}, \mathrm{DMF}$.

diastereoisomers, according to $\mathrm{NMR}{ }^{13} \mathrm{C}$ experiments. Moreover, the yields in these microbial reductions are low. Nevertheless, the use of Aspergillus niger for the bioconversions would allow the synthesis of alcohols with the $R$ absolute configuration at $\mathrm{C}_{6}$ or $\mathrm{C}_{7}$.

After the reduction step, the deprotection of the keto acid group was required. This necessitates the hydrolysis of the nitrile group and the oxidation of the carbon-carbon double bond.

\subsection{Hydrolysis of nitrile group}

The hydrolysis step must take place before the oxidation step in order to avoid the formation of an unstable $\alpha$-ketonitrile group. Initially, we wanted to hydrolyse enzymatically the compounds $\mathbf{8 a}, \mathbf{8 b}$ and $\mathbf{9}$. Indeed, mild reaction conditions (pH 7 and room temperature) do not necessitate hydroxyl groups protection. But, preliminary analytic assays have showed that the compounds $\mathbf{8 a}, \mathbf{8 b}$ and $\mathbf{9}$ were not substrates of nitrile hydratase or nitrilase from Rhodococcus equi A4. Because of this we performed the hydrolysis step chemically. First, the hydroxyl groups were protected as benzyl ethers by reaction with benzyl bromide. Compounds 10a, 10b and 11 were obtained in yields from 61 to $69 \%$ (Scheme 6). Secondly, we carried out the hydrolysis of the nitrile group at $110^{\circ} \mathrm{C}$ under alkaline conditions. ${ }^{14}$ The compounds 10b and $\mathbf{1 1}$ were stable and the hydrolysis of nitrile function is complete after 9 days. The corresponding carboxylates were esterified with methyl iodide. Methyl esters $\mathbf{1 2}$ and $\mathbf{1 3}$ have been isolated with yields of 78 and $73 \%$, respectively (Scheme 6). These were easily characterized by ${ }^{13} \mathrm{C}$ NMR spectroscopy since all signals were assigned: $J$ mod experiments confirmed the disappearance of the nitrile function (about $119 \mathrm{ppm}$ ) and the presence of methyl ester near $177 \mathrm{ppm}$.

Completion of the synthesis of KDO and DAH is simple since these $\alpha$-methylene esters are known to lead to ulosonic acids by oxidation of the carbon-carbon double bond according to methods widely described in the literature. ${ }^{15}$

\section{Conclusion}

We have demonstrated that complex monosaccharides such as ulosonic acids can be synthesised by a chemo-enzymatic strategy different from their biosynthesis. In our study, all the asymmetric carbon configurations were determined by an enzymatic step: a lipase resolution or a microbial reduction for $\mathrm{C}_{4}$, an aldolase catalysed $\mathrm{C}-\mathrm{C}$ bond formation for $\mathrm{C}_{5}-\mathrm{C}_{6}$ in the case of $\mathrm{KDO}$ and a TK catalysed $\mathrm{C}-\mathrm{C}$ bond formation for $\mathrm{C}_{5}-\mathrm{C}_{6}$ in the case of DAH. Finally, $\mathrm{C}_{7}$ (KDO or epimer) and $\mathrm{C}_{6}$ (DAH or epimer) were obtained by enzymatic or microbial reduction. The key step in the synthesis was catalysed by RAMA and TK which appear as complementary tools in organic chemistry.

Thus, this method is a novel and versatile approach to the chemoenzymatic synthesis of ulosonic acids. Indeed, it allowed the preparation of various precursors and analogues of $\mathrm{DAH}$ and $\mathrm{KDO}$ which are inaccessible by other chemoenzymatic or chemical approaches.

\section{Experimental}

\subsection{General methods}

Rabbit muscle aldolase (E.C. 4.1.2.13), acid phytase from Aspergillus ficuum (E.C. 3.1.3.8), L-sorbitol dehydrogenase from sheep liver (E.C. 1.1.1.14), and formate dehydrogenase from yeast (E.C. 1.2.1.2) were purchased from Sigma. ${ }^{1} \mathrm{H}(400.134 \mathrm{MHz})$ and ${ }^{13} \mathrm{C}(100.61 \mathrm{MHz})$ spectra were recorded on a Bruker AC 400 spectrometer. Mass spectra were obtained on a Helwett-Packard 5989 A spectrometer. Optical rotations were determined on a JASCO polarimeter. IR spectra were recorded on a Perkin-Elmer 881 spectrophotometer. UV analyses were performed on a Hitachi (U-2010) spectrophotometer. Solvents were distilled over an appropriate desiccant and stored under argon. Transketolase was produced and purified in our laboratory as precedently described. ${ }^{16}$ All reagents were obtained from Aldrich, TLC plates of silica gel 60F254 from Merck. 
Merck silica gel for column chromatography 60/230-400 and 60/40-63 mesh were used. Aldol condensation was monitored enzymatically by DHAP consumption. ${ }^{17}$ The phosphate-catalysed hydrolysis was monitored by TLC (silica gel from Merck). DHAP was prepared and assayed according to Gefflaut et al. ${ }^{11}$ The microorganisms were all laboratory-grown except freeze-dried baker's yeast, which was a commercial product (VAHINE, Monteux, France). Preculture and culture conditions for the fungus Aspergillus niger ATCC 9142 have already been described elsewhere. ${ }^{18}$

\subsection{Synthesis with RAMA}

4.2.1. (+)-6-Deoxy-6-(1'-cyanovinyl)-( $\alpha, \beta)$-D-fructofuranose 5a. (S)-(-)-4-Hydroxy-2-methylene-5-oxo-pentanenitrile 3 was formed in situ as follows: the dimethyl acetal $(S)$-(-)-5,5-dimethoxy-4-hydroxy-2-methylene-pentanenitrile $1(7.63 \mathrm{mmol})$ was dissolved in water $(33 \mathrm{~mL})$, and Dowex 50W-X8 $\left(\mathrm{H}^{+}\right.$form, 200-400 mesh) was added until $\mathrm{pH}<2$. The mixture was heated at $45^{\circ} \mathrm{C}$ for $12 \mathrm{~h}$, and then the resin was filtered off and washed with water. A solution of DHAP $(29.07 \mathrm{~mL}, 5.56 \mathrm{mmol})$ was added, and the mixture was adjusted to $\mathrm{pH} 7.5$ with $1 \mathrm{~N} \mathrm{NaOH}$. RAMA $(250 \mathrm{U})$ was added, the mixture (total volume $=50.9 \mathrm{~mL}$ ) was stirred gently at rt. After $48 \mathrm{~h}$ DHAP analysis indicated $100 \%$ conversion, the $\mathrm{pH}$ was adjusted to 3.9 with $1 \mathrm{~N} \mathrm{HCl}$. Acid phytase $(250 \mathrm{U})$ was added and the mixture was heated at $30{ }^{\circ} \mathrm{C}$ for $24 \mathrm{~h}$. Water was removed under reduced pressure, and $(+)-6$-deoxy-6-( $1^{\prime}$-cyanovinyl $)-(\alpha, \beta)$-D-fructofuranose $\mathbf{5 a}$ was purified by silica gel chromatography $\left(\mathrm{CH}_{2} \mathrm{Cl}_{2} / \mathrm{MeOH}\right.$, 90: 10) to yield $897.4 \mathrm{mg}$ as colorless oil $(4.17 \mathrm{mmol}: 75 \%$ from DHAP). $[\alpha]_{\mathrm{D}}^{25}=+12.7$ (c 2.22, $\left.\mathrm{MeOH}\right) . R_{\mathrm{f}}=0.27\left(\mathrm{CH}_{2} \mathrm{Cl}_{2} /\right.$ $\mathrm{MeOH}, 90: 10$ ). ${ }^{1} \mathrm{H}$ NMR (400.134 MHz, $\left.\mathrm{CD}_{3} \mathrm{OD}\right) \delta: 6.16$ (s, $\left.1 \mathrm{H}, \mathrm{H}_{9}\right) ; 6.14\left(\mathrm{~s}, 1 \mathrm{H}, \mathrm{H}_{\mathrm{g}}\right) ; 4.25-4.10\left(\mathrm{~m}, 2 \mathrm{H}, \mathrm{H}_{3}\right.$ and $\left.\mathrm{H}_{4}\right) ; 4.05-$ $4.00\left(\mathrm{~m}, 1 \mathrm{H}, \mathrm{H}_{5}\right) ; 3.8\left(\mathrm{~s}, 2 \mathrm{H}, \mathrm{H}_{1}\right) ; 2.82-2.70\left(\mathrm{~m}, 2 \mathrm{H}, \mathrm{H}_{6}\right) .{ }^{13} \mathrm{C}$ NMR (100.61 MHz, CD 3 OD) $\delta: 5 a$ (major, 90\%) $\delta: 134.5$ (C9); 120.7 (C8); 119.9 (C7); 103.4 (C2); 81.7/80.2/79.9 (C3, C4, C5); 64.6(C1);39.0(C6). 5a (minor, 10\%) $\delta: 134.6(\mathrm{C} 9) ; 120.8$ (C8); 120.1 (C7); 106.3 (C2); 84.2/80.8/80.05 (C3, C4, C5); $68.0(\mathrm{C} 1) ; 39.9(\mathrm{C} 6)$. IR (neat) $3351(\mathrm{O}-\mathrm{H}) ; 2360(\mathrm{C} \equiv \mathrm{N}) ; 1641$ $(\mathrm{C}=\mathrm{C}) \mathrm{cm}^{-1}$. MS $\left.\left(\mathrm{Cl} / \mathrm{CH}_{4}\right)=256 \quad\left(\mathrm{M}+\mathrm{C}_{3} \mathrm{H}_{5}\right)^{+}\right) ; 244$ $\left(\left(\mathrm{M}+\mathrm{C}_{2} \mathrm{H}_{5}\right)^{+}\right) ; 216\left((\mathrm{M}+\mathrm{H})^{+}\right) ; 198\left(\left(\mathrm{MH}-\mathrm{H}_{2} \mathrm{O}\right)^{+}\right)$.

4.2.2. (-)-6-Deoxy-6-( $1^{\prime}$-cyanovinyl)- $(\alpha, \beta)$-L-sorbofuranose 5b. To solution of $(R)-(+)$-4-hydroxy-2-methylene-5oxo-pentanenitrile $3(32 \mathrm{~mL})$ prepared as described previously (dimethyl acetal; $6.56 \mathrm{mmol}$ ) was mixed $22.4 \mathrm{~mL}$ of a solution containing $4.72 \mathrm{mmol}$ of DHAP, and the resulting solution was adjusted to $\mathrm{pH} 7.5$ with $1 \mathrm{~N} \mathrm{NaOH}$. $250 \mathrm{U}$ of RAMA were added. The total volume was ca. $57.7 \mathrm{~mL}$. After $46 \mathrm{~h}$ DHAP analysis indicated $100 \%$ conversion, the $\mathrm{pH}$ was adjusted to 3.9 with $1 \mathrm{~N} \mathrm{HCl}$. Acid phytase $(250 \mathrm{U})$ was added and the mixture was heated at $30{ }^{\circ} \mathrm{C}$ for $24 \mathrm{~h}$. Water was removed under reduced pressure, and (-)-6-deoxy-6-( $1^{\prime}$-cyanovinyl $)-(\alpha, \beta)$ L-sorbofuranose $\mathbf{5 b}$ was purified by silica gel chromatography $\left(\mathrm{CH}_{2} \mathrm{Cl}_{2} / \mathrm{MeOH}, 90: 10\right)$ to yield $730.6 \mathrm{mg}$ as colorless oil $\left(72 \%\right.$ from DHAP). $[\alpha]_{\mathrm{D}}^{25}=-22.6$ (c 1.72, $\mathrm{MeOH}) . \quad R_{\mathrm{f}}=0.39 \quad\left(\mathrm{CH}_{2} \mathrm{Cl}_{2} / \mathrm{MeOH}, \quad 90: 10\right) .{ }^{1} \mathrm{H} \quad \mathrm{NMR}$ $\left(400.134 \mathrm{MHz}, \mathrm{CD}_{3} \mathrm{OD}\right) \delta: 5.99\left(\mathrm{~s}, 1 \mathrm{H}, \mathrm{H}_{9}\right): 5.98(\mathrm{~s}, 1 \mathrm{H}$, $\mathrm{H}_{\mathrm{g}}$ ); 4.54 (ddd, $\left.1 \mathrm{H}, J=8.8,4.9,4.4 \mathrm{~Hz}, \mathrm{H}_{5}\right) ; 4.27$ (dd, $1 \mathrm{H}$, $\left.J=4.4,2.9 \mathrm{~Hz}, \mathrm{H}_{4}\right) ; 4.27\left(\mathrm{~d}, 1 \mathrm{H}, J=2.9 \mathrm{~Hz}, \mathrm{H}_{3}\right) ; 3.57(\mathrm{~s}, 2 \mathrm{H}$, $\left.\mathrm{H}_{1}\right) ; 2.75\left(\mathrm{dd}, 1 \mathrm{H}, J=14.8,4.9 \mathrm{~Hz}, \mathrm{H}_{6}\right) ; 2.68(\mathrm{dd}, 1 \mathrm{H}$, $\left.J=14.8,8.8 \mathrm{~Hz}, \mathrm{H}_{6^{\prime}}\right) .{ }^{13} \mathrm{C}$ NMR $\left(100.61 \mathrm{MHz}, \mathrm{CD}_{3} \mathrm{OD}\right) \delta$ : 5b (major, 88\%) $\delta$ : 134.2 (C9); 121.3 (C8); 120.0 (C7); 104.3 (C2); 81.0/78.2/77.6 (C3, C4, C5); 65.7 (C1); 35.7 (C6). 5b (minor, 12\%) $\delta$ : 134.4 (C9); 121.45 (C8); 120.2 (C7); 107.4 (C2); 81.8/78.6/78.3(C3, C4, C5); 66.7 (C1); 36.9 (C6). IR (neat) $3351(\mathrm{O}-\mathrm{H}) ; 2360(\mathrm{C} \equiv \mathrm{N}) ; 1641$ $(\mathrm{C}=\mathrm{C}) \mathrm{cm}^{-1}$. MS $\left(\mathrm{CI} / \mathrm{CH}_{4}\right)=m / z 256\left(\left(\mathrm{M}+\mathrm{C}_{3} \mathrm{H}_{5}\right)^{+}\right) ; 244$ $\left(\left(\mathrm{M}+\mathrm{C}_{2} \mathrm{H}_{5}\right)^{+}\right) ; 216\left((\mathrm{M}+\mathrm{H})^{+}\right) ; 198\left(\left(\mathrm{MH}-\mathrm{H}_{2} \mathrm{O}\right)^{+}\right)$.

4.2.3. (+)-6-Deoxy-6-( $1^{\prime}$-éthyl-oxycarbonyl-2'-vinyl)$(\alpha, \beta)$-D-fructofuranose $6 \mathrm{a}$ and (-)-6-deoxy-6-(1'-éthyloxycarbonyl-2' -vinyl)-( $\alpha, \beta)$-D-sorbofuranose 6 b. To solution of 4-hydroxy-2-methylene-5-oxo-pentanoic acid ethyl ester $4(26 \mathrm{~mL})$ prepared as described previously (dimethyl acetal; $5.34 \mathrm{mmol}$ ) was mixed $17.4 \mathrm{~mL}$ of a solution containing $3.87 \mathrm{mmol}$ of DHAP, and the resulting solution was adjusted to $\mathrm{pH} 7.5$ with $1 \mathrm{~N} \mathrm{NaOH}$. $250 \mathrm{U}$ of RAMA were added. The total volume was ca. $43.7 \mathrm{~mL}$. At 24 and 48 h, $50 \mathrm{U}$ of RAMA were added. After $56 \mathrm{~h} \mathrm{DHAP}$ analysis indicated $100 \%$ conversion, the $\mathrm{pH}$ was adjusted to 3.9 with $1 \mathrm{~N} \mathrm{HCl}$. Acid phytase $(250 \mathrm{U})$ was added and the mixture was heated at $30^{\circ} \mathrm{C}$ for $24 \mathrm{~h}$. Water was removed under reduced pressure. The two diastereoisomers $\mathbf{6 a}$ and $\mathbf{6 b}$ were purified and separated by silica gel chromatography $\left(\mathrm{CH}_{2} \mathrm{Cl}_{2} / \mathrm{MeOH}, 98: 2\right.$ to $\left.85: 15\right)$ to yield $111.5 \mathrm{mg}(11 \%)$ $(6 \mathbf{6} / \mathbf{6} \mathbf{b}=1: 1)$ as colorless oil.

4.2.3.1. (+)-6-Deoxy-6-(1'-éthyl-oxycarbonyl-2' vinyl)-( $\boldsymbol{\alpha}, \boldsymbol{\beta})$-D -fructofuranose 6 a. $[\alpha]_{\mathrm{D}}^{25}=+8 \quad(c \quad 2.25$, $\mathrm{MeOH}) . \quad R_{\mathrm{f}}=0.15 \quad\left(\mathrm{CH}_{2} \mathrm{Cl}_{2} / \mathrm{MeOH}, \quad 85: 15\right) .{ }^{1} \mathrm{H} \quad \mathrm{NMR}$ $\left(400.134 \mathrm{MHz}, \mathrm{CD}_{3} \mathrm{OD}\right) \delta: 6.13\left(\mathrm{~s}, 1 \mathrm{H}, \mathrm{H}_{9}\right) ; 6.01(\mathrm{~s}, 1 \mathrm{H}$, $\left.\mathrm{H}_{\mathrm{g}}\right) ; 4.30\left(\mathrm{q}, 2 \mathrm{H}, J=7.5 \mathrm{~Hz}, \mathrm{CH}_{2}\right.$ ester $) ; 3.85-3.92(\mathrm{~m}, 1 \mathrm{H}$, $\left.\mathrm{H}_{4}\right) ; 3.86\left(\mathrm{~d}, 1 \mathrm{H}, J=7.5 \mathrm{~Hz} ; \mathrm{H}_{3}\right) ; 3.61-3.66\left(\mathrm{~m}, 1 \mathrm{H}, \mathrm{H}_{5}\right)$; $3.37\left(\mathrm{~s}, 2 \mathrm{H}, \mathrm{H}_{1}\right) ; 2.36-2.19\left(\mathrm{~m}, 2 \mathrm{H}, \mathrm{H}_{6}\right) ; 1.37(\mathrm{t}, 3 \mathrm{H}$, $J=7.5 \mathrm{~Hz}, \mathrm{CH}_{3}$ ester). ${ }^{13} \mathrm{C}$ NMR $\left(100.61 \mathrm{MHz}, \mathrm{CD}_{3} \mathrm{OD}\right) \delta$ : 6a (major, $78 \%$ ) 167.9 (C8); 144.9 (C7); 125.7 (C9); 104.5 (C2); 79.2/78.7/77.1 (C3, C4, C5); $66.3(\mathrm{C} 1) ; 60.4\left(\mathrm{CH}_{2}\right.$ ester); 36.3 (C6); $19.5\left(\mathrm{CH}_{3}\right.$ ester), 6a (minor, $\left.22 \%\right) 167.9$ (C8); 144.7 (C7); 125.3 (C9); 108.1 (C2); 84.4/81.4/78.25 (C3, C4, C5); 65.4 (C1); $60.4\left(\mathrm{CH}_{2}\right.$ ester); 33.7 (C6); 19.5 $\left(\mathrm{CH}_{3}\right.$ ester). IR (neat) $3354(\mathrm{O}-\mathrm{H}) ; 1735(\mathrm{C}=\mathrm{O}) ; 1637$ $(\mathrm{C}=\mathrm{C}) ; 1041 \quad(\mathrm{C}-\mathrm{O}) \quad \mathrm{cm}^{-1}$. MS $\left(\mathrm{CI} / \mathrm{CH}_{4}\right)=m / z \quad 263$ $\left((\mathrm{M}+\mathrm{H})^{+}\right) ; 245\left(\left(\mathrm{MH}-\mathrm{H}_{2} \mathrm{O}\right)^{+}\right)$.

4.2.3.2. (-)-6-Deoxy-6-(1'-éthyl-oxycarbonyl-2' vinyl)-( $\boldsymbol{\alpha}, \boldsymbol{\beta})$-D-sorbofuranose 6 b. $[\alpha]_{\mathrm{D}}^{25}=-5.6$ (c 1.5 , $\mathrm{MeOH}) . \quad R_{\mathrm{f}}=0.25 \quad\left(\mathrm{CH}_{2} \mathrm{Cl}_{2} / \mathrm{MeOH}, 85: 15\right),{ }^{1} \mathrm{H} \quad \mathrm{NMR}$ $\left(400.134 \mathrm{MHz}, \mathrm{CD}_{3} \mathrm{OD}\right) \delta: 6.10\left(\mathrm{~s}, 1 \mathrm{H}, \mathrm{H}_{9}\right) ; 6.05(\mathrm{~s}, 1 \mathrm{H}$, $\left.\mathrm{H}_{\mathrm{g}}\right) ; 4.25$ (q, $2 \mathrm{H}, J=6.5 \mathrm{~Hz}, \mathrm{CH}_{2}$ ester); 4.04-4.14 (m, 2H, $\mathrm{H}_{4}$ et $\left.\mathrm{H}_{5}\right) ; 3.89\left(\mathrm{~d}, 1 \mathrm{H}, J=4.5 \mathrm{~Hz}, \mathrm{H}_{3}\right) ; 3.42\left(\mathrm{~s}, 2 \mathrm{H}, \mathrm{H}_{1}\right)$; $2.09-2.26\left(\mathrm{~m}, 2 \mathrm{H}, \mathrm{H}_{6}\right) ; 1.25\left(\mathrm{t}, 3 \mathrm{H}, J=6.5 \mathrm{~Hz}, \mathrm{CH}_{3}\right.$ ester). ${ }^{13} \mathrm{C}$ NMR (100.61 MHz, CD $\left.{ }_{3} \mathrm{OD}\right) \delta: \mathbf{6 b}$ (major, $83 \%$ ) 167.9 (C8); 144.7 (C7); 125.5 (C9); 103.8 (C2); 80.5/79.4/78.7 (C3, C4, C5); 66.4 (C1); $61.4\left(\mathrm{CH}_{2}\right.$ ester); 34.7 (C6); 21.5 $\left(\mathrm{CH}_{3}\right.$ ester). 6b (minor, 17\%) $167.9(\mathrm{C} 8) ; 144.9(\mathrm{C} 7) ; 125.0$ (C9); 105.7 (C2); 79.6/78.9/77.7 (C3, C4, C5); 67.1 (C1); $61.4\left(\mathrm{CH}_{2}\right.$ ester $) ; 34.7$ (C6); $21.5\left(\mathrm{CH}_{3}\right.$ ester). IR (neat) 3354 $(\mathrm{O}-\mathrm{H}) ; 1735(\mathrm{C}=\mathrm{O}) ; 1637(\mathrm{C}=\mathrm{C}) ; 1041(\mathrm{C}-\mathrm{O}) \mathrm{cm}^{-1}$. MS $\left(\mathrm{CI} / \mathrm{CH}_{4}\right)=m / z 263\left((\mathrm{M}+\mathrm{H})^{+}\right) ; 245\left(\left(\mathrm{MH}-\mathrm{H}_{2} \mathrm{O}\right)^{+}\right)$.

\subsection{Synthesis with TK}

4.3.1. (-)-(4R,5S)-4,5,7-Trihydroxy-2-methylene-6-oxoheptanenitrile $7.40 \mathrm{~mL}$ of enzyme extract containing $200 \mathrm{U}$ of TK, $290 \mathrm{mg}$ of Tris buffer $(50 \mathrm{mM}, \mathrm{pH} 7.5), 0.6 \mathrm{~g}$ of $(R)$-(+)-4-hydroxy-2-methylene-5-oxo-pentanenitrile 3 
(4.79 mmol, $100 \mathrm{mM}), 0.55 \mathrm{~g}$ of commercial hydroxypyruvate $(5 \mathrm{mmol}, \quad 100 \mathrm{mM}), 19.5 \mathrm{mg}$ of $\mathrm{MgCl}_{2}$ $\left(9.58 .10^{-2} \mathrm{mmol}, 2 \mathrm{mM}\right)$, and $66 \mathrm{mg}\left(1.44 .10^{-2} \mathrm{mmol}\right.$, $3 \mathrm{mM}$ ) thiamine pyrophosphate (TPP) were placed in a round-bottomed flask. The reaction mixture was deoxygenated with argon and left at $\mathrm{rt}$ in the dark. After complete disappearance of hydroxypyruvate $(14 \mathrm{~h}), \mathrm{MeOH}(200 \mathrm{~mL})$ was added and the precipitate was removed by centrifugation. The supernatant was concentrated under reduced pressure to a thick syrup. Purification of this syrup by chromatography on silica gel afforded $(-)-(4 R, 5 S)-4,5,7$ trihydroxy-2-methylene-6-oxo-heptanenitrile 7 as a colorless oil $(648 \mathrm{mg}, 73 \%) .[\alpha]_{\mathrm{D}}^{25}=+8.5(c$ 2.17, $\mathrm{MeOH})$. $R_{\mathrm{f}}=0.48\left(\mathrm{CH}_{2} \mathrm{Cl}_{2} / \mathrm{MeOH}, 8: 2\right) .{ }^{1} \mathrm{H}$ NMR $(400.134 \mathrm{MHz}$, $\left.\mathrm{CDCl}_{3}\right) \delta: 6.25\left(\mathrm{~s}, 1 \mathrm{H}, \mathrm{H}_{8}\right) ; 6.15\left(\mathrm{~s}, 1 \mathrm{H}, \mathrm{H}_{8^{\prime}}\right) ; 4.76(\mathrm{~d}, 1 \mathrm{H}$, $\left.J=12 \mathrm{~Hz}, \mathrm{H}_{7}\right) ; 4.64\left(\mathrm{~d}, 1 \mathrm{H}, J=12 \mathrm{~Hz}, \mathrm{H}_{7^{\prime}}\right) ; 4.50(\mathrm{~d}, 1 \mathrm{H}$, $\left.J=3 \mathrm{~Hz}, \mathrm{H}_{5}\right) ; 4.39\left(\mathrm{~m}, 1 \mathrm{H}, \mathrm{H}_{4}\right) ; 2.73\left(\mathrm{~d}, 2 \mathrm{H}, J=6 \mathrm{~Hz}, \mathrm{H}_{3}\right)$. ${ }^{13} \mathrm{C} \mathrm{NMR}\left(100.61 \mathrm{MHz}, \mathrm{CDCl}_{3}\right) \delta: 213.4$ (C6); 134.6 (C8); 121.3 (C2); 119.8 (C1); 78.9 (C5); 71.6 (C4); 68.1 (C7); $39.55(\mathrm{C} 3)$. IR (neat) $3364(\mathrm{O}-\mathrm{H}) ; 2227(\mathrm{CN}) ; 1733(\mathrm{C}=\mathrm{O})$ $\mathrm{cm}^{-1}$. MS $\left(\mathrm{CI} / \mathrm{CH}_{4}\right)=m / z 186\left((\mathrm{M}+\mathrm{H})^{+}\right)$. HRMS calcd for 208.0586, found $208.0587(\mathrm{M}+\mathrm{H})^{+}$.

\subsection{Enzymatic reduction of RAMA and TK adducts}

4.4.1. General procedure for the reduction of RAMA and TK adducts with sorbitol dehydrogenase. To a solution of RAMA or TK adduct $\mathbf{5 a}, \mathbf{5} \mathbf{b}$ or $\mathbf{7}(0.1 \mathrm{mM})$ in $100 \mathrm{mM}$ phosphate buffer $(\mathrm{pH} \mathrm{7.0)}$ were added sodium formate (3 equiv.), NADH sodium salt ( 0.05 equiv.), L-sorbitol dehydrogenase (E.C. 1.1.1.14, $15 \mathrm{U}$ ) and formate dehydrogenase (E.C. 1.2.1.2, $15 \mathrm{U}$ ). The mixture reaction was stirred at room temperature until the ketose was disappeared completely as indicated by TLC analysis $\left(\mathrm{CH}_{2} \mathrm{Cl}_{2} / \mathrm{MeOH}, 80: 20\right)$. The mixture was concentrated under reduced pressure and chromatographed over silica gel $\left(\mathrm{CH}_{2} \mathrm{Cl}_{2} / \mathrm{MeOH}, 95: 5\right.$ to $\left.85: 15\right)$ to give purified product as $8 \mathrm{a}, 8 \mathrm{~b}$ or 9 .

4.4.1.1. (+)-(4R,5R,6S,7S)-4,5,6,7,8-Pentahydroxy-2methylene-octanenitrile 8a. $[\alpha]_{\mathrm{D}}^{25}=+11.7(c 0.7, \mathrm{MeOH})$. $R_{\mathrm{f}}=0.25\left(\mathrm{CH}_{2} \mathrm{Cl}_{2} / \mathrm{MeOH}, 80: 20\right) .{ }^{1} \mathrm{H}$ NMR $(400.134 \mathrm{MHz}$, $\left.\mathrm{CD}_{3} \mathrm{OD}\right) \delta: 6.20\left(\mathrm{~s}, 1 \mathrm{H}, \mathrm{H}_{9^{\prime}}\right) ; 6.11\left(\mathrm{~s}, 1 \mathrm{H}, \mathrm{H}_{9}\right) ; 4.17(\mathrm{~m}, 1 \mathrm{H}$, $\left.\mathrm{H}_{6}\right) ; 4.02\left(\mathrm{~m}, 1 \mathrm{H}, \mathrm{H}_{5}\right) ; 3.95\left(\mathrm{~m}, 1 \mathrm{H}, \mathrm{H}_{7}\right) ; 3.85\left(\mathrm{~m}, 1 \mathrm{H}, \mathrm{H}_{4}\right)$; $3.75\left(\mathrm{~m}, 1 \mathrm{H}, \mathrm{H}_{8}\right) ; 2.95\left(\mathrm{dd}, 1 \mathrm{H}, \mathrm{H}_{3}, J=15,8 \mathrm{~Hz}\right) ; 2.85$ (dd, $\left.1 \mathrm{H}, \mathrm{H}_{3^{\prime}}, J=15,6 \mathrm{~Hz}\right),{ }^{13} \mathrm{C}$ NMR $\left(100.61 \mathrm{MHz}, \mathrm{CD}_{3} \mathrm{OD}\right) \delta$ : 134.0 (C9); 122.0 (C2); 120.1 (C1); 75.1/74.8/73.5/72.6 (C4, C5, C6, C7); 64.7 (C8); 40.1(C3). IR (neat) 3354 (O-

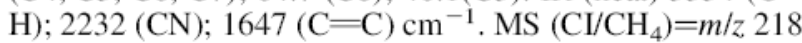
$\left((\mathrm{M}+\mathrm{H})^{+}\right)$

4.4.1.2. (-)-(4S,5R,6S,7S)-4,5,6,7,8-Pentahy droxy-2methylene-octanenitrile $\mathbf{8 b}$. $[\alpha]_{\mathrm{D}}^{25}=-10.9 \quad(c)$ 1.6, $\mathrm{MeOH}) . \quad R_{\mathrm{f}}=0.17 \quad\left(\mathrm{CH}_{2} \mathrm{Cl}_{2} / \mathrm{MeOH}, \quad 80: 20\right) .{ }^{1} \mathrm{H} \quad \mathrm{NMR}$ $\left(400.134 \mathrm{MHz}, \mathrm{CD}_{3} \mathrm{OD}\right) \delta: 6.20\left(\mathrm{~s}, 1 \mathrm{H}, \mathrm{H}_{9^{\prime}}\right) ; 6.11(\mathrm{~s}, 1 \mathrm{H}$, $\left.\mathrm{H}_{9}\right) ; 4.17\left(\mathrm{~m}, 1 \mathrm{H}, \mathrm{H}_{6}\right) ; 4.02\left(\mathrm{~m}, 1 \mathrm{H}, \mathrm{H}_{5}\right) ; 3.95\left(\mathrm{~m}, 1 \mathrm{H}, \mathrm{H}_{7}\right)$; $3.85\left(\mathrm{~m}, 1 \mathrm{H}, \mathrm{H}_{4}\right) ; 3.75\left(\mathrm{~m}, 1 \mathrm{H}, \mathrm{H}_{8}\right) ; 2.95\left(\mathrm{dd}, 1 \mathrm{H}, \mathrm{H}_{3}, J=15\right.$, $8 \mathrm{~Hz}) ; 2.85\left(\mathrm{dd}, 1 \mathrm{H}, \mathrm{H}_{3^{\prime}}, \quad J=15,6 \mathrm{~Hz}\right),{ }^{13} \mathrm{C} \quad \mathrm{NMR}$ $\left(100.61 \mathrm{MHz}, \mathrm{CD}_{3} \mathrm{OD}\right) \delta$ : 134.1 (C9); 122.1 (C2); 120.0 (C1); 74.8/73.55/72.9/71.2 (C4, C5, C6, C7); 64.6 (C8); $40.0(\mathrm{C} 3)$. IR (neat) $3354(\mathrm{O}-\mathrm{H}) ; 2232(\mathrm{CN}) ; 1647(\mathrm{C}=\mathrm{C})$ $\mathrm{cm}^{-1}$. MS $\left(\mathrm{CI} / \mathrm{CH}_{4}\right)=m / z, 218\left((\mathrm{M}+\mathrm{H})^{+}\right)$.

4.4.1.3. (+)-(4R,5S,6S)-4,5,6,7-Tétrahydroxy-2methylene-heptanenitrile $9 . \quad[\alpha]_{\mathrm{D}}^{25}=+4.6 \quad(c) 1.22$, $\mathrm{MeOH}) . \quad R_{\mathrm{f}}=0.48 \quad\left(\mathrm{CH}_{2} \mathrm{Cl}_{2} / \mathrm{MeOH}, \quad 80: 20\right) .{ }^{1} \mathrm{H} \quad \mathrm{NMR}$ $\left(400.134 \mathrm{MHz}, \mathrm{CD}_{3} \mathrm{OD}\right) \delta: 6.0\left(\mathrm{~s}, 1 \mathrm{H}, \mathrm{H}_{8}\right) ; 5.93(\mathrm{~s}, 1 \mathrm{H}$, $\left.\mathrm{H}_{8^{\prime}}\right) ; 3.96\left(\mathrm{~m}, 1 \mathrm{H}, J=8.9,4.4 \mathrm{~Hz}, \mathrm{H}_{6}\right) ; 3.77(\mathrm{dd}, 1 \mathrm{H}, J=9.2$, $\left.4.8 \mathrm{~Hz}, \mathrm{H}_{5}\right) ; 3.68\left(\mathrm{dd}, 1 \mathrm{H}, J=14.9,7.0 \mathrm{~Hz}, \mathrm{H}_{7}\right) ; 3.63(\mathrm{dd}$, $\left.1 \mathrm{H}, J=14.9,5.6 \mathrm{~Hz}, \mathrm{H}_{7^{\prime}}\right) ; 2.58\left(\mathrm{dd}, 1 \mathrm{H}, J=8,4.2 \mathrm{~Hz}, \mathrm{H}_{3}\right)$; $2.52\left(\mathrm{dd}, 1 \mathrm{H}, J=9,5.5 \mathrm{~Hz}, \mathrm{H}_{3^{\prime}}\right),{ }^{13} \mathrm{C}$ NMR $(100.61 \mathrm{MHz}$, $\left.\mathrm{CD}_{3} \mathrm{OD}\right) \delta$ : 134.1 (C8); 122.1 (C2); 120.1 (C1); 74.1 (C5); 74.0 (C6); 71.7 (C4); 64.5 (C7); 40.0 (C3). IR (neat) 3364 $(\mathrm{O}-\mathrm{H}) ; 2227 \quad(\mathrm{CN}) \quad \mathrm{cm}^{-1} . \quad \mathrm{MS} \quad(\mathrm{GC} / \mathrm{CI})=m / z \quad 188$ $\left((\mathrm{M}+\mathrm{H})^{+}\right)$.

4.4.2. General procedure for the reduction of RAMA and TK adducts with freeze-dried baker's yeast or Aspergillus niger. After culture at $27^{\circ} \mathrm{C}$ for the times as indicated by Besse and co-workers, the fungus was filtered on sintered glass or centrifuged, and then washed four times with $\mathrm{NaCl}$ solution $\left(8 \mathrm{~g} \mathrm{~L}^{-1}\right)$. Mycelium or freeze-dried baker's yeast $(5 \mathrm{~g})$ was placed in a $500 \mathrm{~mL}$ conical flask with $50 \mathrm{~mL}$ of distilled water and $50 \mu \mathrm{L}$ of substrate. After incubation at $27^{\circ} \mathrm{C}$ on a rotating table set at $200 \mathrm{rpm}$, the mixture was filtered on sintered glass or centrifuged for $10 \mathrm{~min}$ at $8000 \mathrm{rpm}$. The liquor was then continuously extracted with ethyl acetate for $24 \mathrm{~h}$. The ethyl acetate phase was dried on $\mathrm{MgSO}_{4}$ and the solvent evapored off under vaccum. The products extracted after bioconversion were separated on a silica gel column. The eluent was $\mathrm{CH}_{2} \mathrm{Cl}_{2} /$ $\mathrm{MeOH}, 95: 5$ to 80:20. Bioconversions were stopped when the ketose was disappeared completely as indicated by TLC analysis $\left(\mathrm{CH}_{2} \mathrm{Cl}_{2} / \mathrm{MeOH}, 80: 20\right)$.

The results were reported on Table 2 .

Table 2. Enzymatic and microbial reduction of the keto group of the KDO and DAH precursors 5 and 7

\begin{tabular}{|c|c|c|c|c|c|c|}
\hline & & IDH & Bake & 's yeast & Asperg & llus niger \\
\hline & {$[\alpha]_{\mathrm{D}}^{25{ }^{\circ} \mathrm{C}}$} & Yield (\%) & {$[\alpha]_{\mathrm{D}}^{25^{\circ} \mathrm{C}}$} & Yield (\%) & {$[\alpha]_{\mathrm{D}}^{25{ }^{\circ} \mathrm{C}}$} & Yield $(\%)$ \\
\hline $5 a$ & -11.7 & $\begin{array}{l}69 \\
(8 \mathrm{a},(S)-\mathrm{C} 7)\end{array}$ & -10.9 & 31 & +5.6 & 17 \\
\hline $5 b$ & -11.2 & $\begin{array}{l}67 \\
(8 b,(S)-C 7)\end{array}$ & -10.7 & 23 & -4.9 & 6 \\
\hline 7 & +4.6 & $(9,(S)-\mathrm{C} 6)$ & +5 & 24 & -2 & 7 \\
\hline
\end{tabular}

4.4.3. General procedure for the benzylation of L-SDH products. To a stirred solution of compound $\mathbf{8 a}, \mathbf{8 b}$, or $\mathbf{9}$ $(60 \mathrm{mM})$ in dry THF was added slowly $\mathrm{NaH}$ (1 equiv. per hydroxyl group) at $-20{ }^{\circ} \mathrm{C}$ under inert atmosphere. After the addition, the mixture reaction was homogeneous, $\mathrm{IN}(\mathrm{Bu})_{4} \quad(0.5$ equiv. per hydroxyl group), and benzyl bromide ( 1 equiv. per hydroxyl group) were added at room temperature. The mixture was stirred for $1 \mathrm{~h}$, then evaporated. Column chromatography (cyclohexane/ethyl acetate, 8:2) gave purified penta or tetrabenzylated compound as $10 \mathrm{a}, 10 \mathrm{~b}$ or 11 .

4.4.3.1. (+)-(4R,5R,6S,7S)-4,5,6,7,8-Pentakis-benzyloxy-2-methylene-octanenitrile 10a. Yield $=61 \%$ (colorless oil). $[\alpha]_{\mathrm{D}}^{25}=+16.9\left(c 1.565, \mathrm{CHCl}_{3}\right) \cdot R_{\mathrm{f}}=0.48($ cyclohexane/ ethyl acetate, 8:2). ${ }^{1} \mathrm{H}$ NMR (400.134 MHz, $\left.\mathrm{CDCl}_{3}\right) \delta: 7.45$ $(\mathrm{m}, 25 \mathrm{H}, \mathrm{H}$ ar. $) ; 5.85\left(\mathrm{~s}, 1 \mathrm{H}, \mathrm{H}_{9}\right) ; 5.60\left(\mathrm{~s}, 1 \mathrm{H}, \mathrm{H}_{9^{\prime}}\right) ; 4.85-$ $4.35\left(\mathrm{~m}, 10 \mathrm{H}, 5 \times \mathrm{OCH}_{2}\right) ; 4.06\left(\mathrm{~m}, 1 \mathrm{H}, \mathrm{H}_{6}\right) ; 3.9\left(\mathrm{~m}, 1 \mathrm{H}, \mathrm{H}_{5}\right)$; $3.84\left(\mathrm{~m}, 1 \mathrm{H}, \mathrm{H}_{7}\right): 3.71\left(\mathrm{~m}, 3 \mathrm{H}, \mathrm{H}_{4}\right.$ and $\left.\mathrm{H}_{8}\right) ; 3.60(\mathrm{dd}, 1 \mathrm{H}$, $\left.J=15,4 \mathrm{~Hz}, \mathrm{H}_{8^{\prime}}\right) ; 2.675\left(\mathrm{dd}, 1 \mathrm{H}, J=16,4 \mathrm{~Hz}, \mathrm{H}_{3}\right) ; 2.60(\mathrm{~d}$, 
$\left.1 \mathrm{H}, J=16 \mathrm{~Hz}, \mathrm{H}_{3^{\prime}}\right) .{ }^{13} \mathrm{C}$ NMR $\left(100.61 \mathrm{MHz}, \mathrm{CDCl}_{3}\right) \delta$ : 138.6/138.4/138.3/138.2/138.1 ( $\left.\mathrm{C}_{\text {ipso }}\right)$; 132.6 (C9); $128.5-$ $127.6\left(\mathrm{C}_{\text {ortho }}, \mathrm{C}_{\text {méta }}\right.$ and $\left.\mathrm{C}_{\text {para }}\right) ; 120.7(\mathrm{C} 2) ; 119.1(\mathrm{C} 1)$; 79.92/79.25/79.1/78.4 (C4, C5, C6, C7); 74.9/74.4/73.4/ $72.8 / 72.1\left(5 \times \mathrm{OCH}_{2}\right) ; 69.6(\mathrm{C} 8) ; 35.9(\mathrm{C} 3)$. IR (neat) 3367 $(\mathrm{O}-\mathrm{H}) ; 2226(\mathrm{CN}) ; 1667$ and $1621(\mathrm{C}=\mathrm{C}) ; 1047(\mathrm{C}-\mathrm{O})$ $\mathrm{cm}^{-1}$. MS $\left(\mathrm{CI} / \mathrm{CH}_{4}\right)=m / z 688\left((\mathrm{M}+\mathrm{H})^{+}\right)$.

4.4.3.2. (-)-(4S,5R,6S,7S)-4,5,6,7,8-Pentakis-benzyloxy-2-methylene-octanenitrile 10b. Yield $=58 \%$ (colorless oil). $[\alpha]_{\mathrm{D}}^{25}=-15.5\left(c 2.06, \mathrm{CHCl}_{3}\right) . R_{\mathrm{f}}=0.31$ (cyclohexane/ ethyl acetate, 8:2). ${ }^{1} \mathrm{H} \mathrm{NMR}\left(400.134 \mathrm{MHz}, \mathrm{CDCl}_{3}\right) \delta: 7.45$ (m, 25H, H ar.); 6.01 (s, 1H, $\left.\mathrm{H}_{9}\right) ; 5.94$ (s, 1H, Ho $) ; 4.90-$ $4.42\left(\mathrm{~m}, 10 \mathrm{H}, 5 \times \mathrm{OCH}_{2}\right) ; 4.03\left(\mathrm{~m}, 1 \mathrm{H}, \mathrm{H}_{6}\right) ; 3.92(\mathrm{~m}, 1 \mathrm{H}$, $\left.\mathrm{H}_{5}\right) ; 3.87\left(\mathrm{~m}, 1 \mathrm{H}, \mathrm{H}_{7}\right) ; 3.74\left(\mathrm{~m}, 3 \mathrm{H}, \mathrm{H}_{4}\right.$ and $\left.\mathrm{H}_{8}\right) ; 3.63(\mathrm{dd}$, $\left.1 \mathrm{H}, J=15,4 \mathrm{~Hz}, \mathrm{H}_{8^{\prime}}\right) ; 2.68\left(\mathrm{dd}, 1 \mathrm{H}, J=16,4 \mathrm{~Hz}, \mathrm{H}_{3}\right) ; 2.62$ $\left(\mathrm{d}, 1 \mathrm{H}, \mathrm{J}=16 \mathrm{~Hz}, \mathrm{H}_{3^{\prime}}\right),{ }^{13} \mathrm{C}$ NMR $\left(100.61 \mathrm{MHz}, \mathrm{CDCl}_{3}\right) \delta$ : 138. 6/138.4/138.3/138.2/138.1 $\left(\mathrm{C}_{\text {ipso }}\right)$; 132.3 (C9); 128.5$127.6\left(\mathrm{C}_{\text {ortho }}, \mathrm{C}_{\text {méta }}\right.$ and $\left.\mathrm{C}_{\text {para }}\right) ; 120.6(\mathrm{C} 2) ; 119.0(\mathrm{C} 1) ; 79.7 /$ 79.1/78.8/78.2 (C4, C5, C6, C7); 74.9/74.4/73.4/72.8/72.1 $\left(5 \times \mathrm{OCH}_{2}\right) ; 69.3(\mathrm{C} 8) ; 33.9(\mathrm{C} 3)$. IR (neat) $3358(\mathrm{O}-\mathrm{H})$; $2227(\mathrm{CN}) ; 1667$ and $1620(\mathrm{C}=\mathrm{C}) ; 1053(\mathrm{C}-\mathrm{O}) \mathrm{cm}^{-1}$. MS $\left(\mathrm{CI} / \mathrm{CH}_{4}\right)=m / z 688\left((\mathrm{M}+\mathrm{H})^{+}\right)$

4.4.3.3. Heptanenitrile 4,4,3,3(+)-(4R,5S,6S)-4,5,6,7tétrakis-benzyloxy-2-methylene-11. Yield $=44 \%$ (colorless oil). $[\alpha]_{\mathrm{D}}^{25}=+7.1$ (c $\left.3.95, \mathrm{CHCl}_{3}\right) . R_{\mathrm{f}}=0.44$ (cyclohexane/ ethyl acetate, 8:2). ${ }^{1} \mathrm{H}$ NMR $\left(400.134 \mathrm{MHz}, \mathrm{CDCl}_{3}\right) \delta$ : $7.42-7.27(\mathrm{~m}, 20 \mathrm{H}, \mathrm{H}$ ar. $) ; 5.83\left(\mathrm{~s}, 1 \mathrm{H}, \mathrm{H}_{8}\right) ; 5.52(\mathrm{~s}, 1 \mathrm{H}$, $\left.\mathrm{H}_{8^{\prime}}\right) ; 4.8-4.48\left(\mathrm{~m}, 8 \mathrm{H}, 4 \times \mathrm{OCH}_{2}\right) ; 3.92\left(\mathrm{~m}, 1 \mathrm{H}, \mathrm{H}_{6}\right) ; 3.88$ $\left(\mathrm{m}, 1 \mathrm{H}, \mathrm{H}_{5}\right) ; 3.68\left(\mathrm{~m}, 2 \mathrm{H}, \mathrm{H}_{4}\right.$ and $\left.\mathrm{H}_{7}\right) ; 3.60(\mathrm{dd}, 1 \mathrm{H}, J=10$, $\left.5.3 \mathrm{~Hz}, \mathrm{H}_{7^{\prime}}\right) ; 2.56\left(\mathrm{dd}, 1 \mathrm{H}, J=14.5,4.4 \mathrm{~Hz}, \mathrm{H}_{3}\right) ; 2.41$ (dd, $\left.1 \mathrm{H}, J=14.5,8.2 \mathrm{~Hz}, \mathrm{H}_{3^{\prime}}\right) .{ }^{13} \mathrm{C} \mathrm{NMR}\left(100.61 \mathrm{MHz}, \mathrm{CDCl}_{3}\right)$ $\delta$ : $135-134.4\left(\mathrm{C}_{\text {ipso }}\right) ; 129.7$ (C8); $125.3-124.5\left(\mathrm{C}_{\text {ortho }}\right.$ $\mathrm{C}_{\text {méta }}$ and $\left.\mathrm{C}_{\text {para }}\right) ; 117.1(\mathrm{C} 2) ; 115.6(\mathrm{C} 1) ; 75.6(\mathrm{C} 5) ; 74.2$ (C6); 73.7 (C4): $71.2 / 70.2 / 70.1 / 69.6\left(4 \times \mathrm{OCH}_{2}\right) ; 66.3$ (C7); $33.0(\mathrm{C} 3)$. IR (neat) $2236(\mathrm{CN}) ; 1659(\mathrm{C}=\mathrm{C}) ; 1027(\mathrm{C}-\mathrm{O})$ $\mathrm{cm}^{-1}$. MS $\left(\mathrm{CI} / \mathrm{CH}_{4}\right)=m / z 688\left((\mathrm{M}+\mathrm{H})^{+}\right)$. HRMS calcd for 548.2801, found $548.2804(\mathrm{M}+\mathrm{H})^{+}$.

4.4.4. General procedure for the hydrolysis of nitrile group. To a solution of penta- or tetrabenzylated compound as $10 \mathrm{~b}$ or $11(3 \mathrm{mM})$ in ethylene glycol, water, THF, and $\mathrm{MeOH}(1: 1: 1: 2)$ was added $\mathrm{NaOH}$ (4 equiv.). The mixture was heaten at $110^{\circ} \mathrm{C}$ for 9 days. Then at rt, carboxylate group was esterified by addition of DMF $(1 \mathrm{mM})$, and methyl iodide (10 equiv.) The mixture reaction was stirred for $24 \mathrm{~h}$, then diluted with water, extracted with $\mathrm{CH}_{2} \mathrm{Cl}_{2}$, dried $\left(\mathrm{MgSO}_{4}\right)$ and evaporated. Column chromatography (cyclohexane/ethyl acetate, 8:2) gave purified methyl ester as 12 or 13 .

4.4.4.1. (-)-(4S,5R,6S,7S)-4,5,6,7,8-Pentakis-benzyloxy-2-methylene-octanoic acid methyl ester 12. Yield $=78 \%$ (colorless oil). $[\alpha]_{\mathrm{D}}^{25}=-4.1\left(c\right.$ 1.0, $\left.\mathrm{CHCl}_{3}\right)$. $R_{\mathrm{f}}=0.33 \quad$ (cyclohexane/ethyl acetate, 8:2). ${ }^{13} \mathrm{C} \quad \mathrm{NMR}$ $\left(100.61 \mathrm{MHz}, \mathrm{CDCl}_{3}\right) \delta: 176.5(\mathrm{C} 1) ; 138.8-138.3\left(\mathrm{C}_{i p s o}\right)$; 134.1 (C9); 125.2 (C2); 79.5/78.6/78.1/78 (C4, C5, C6, C7); $74.3 / 73.3 / 73.1 / 72.6 / 72.4\left(5 \times \mathrm{OCH}_{2}\right) ; 69.9(\mathrm{C} 8) ; 33.7$ (C3); $14.8\left(\mathrm{CH}_{3}\right.$ ester). IR (neat) $2923(\mathrm{C}-\mathrm{H}) ; 1731(\mathrm{C}=\mathrm{O}) ; 1667$ $(\mathrm{C}=\mathrm{C}) ; 1090(\mathrm{C}-\mathrm{O}) \mathrm{cm}^{-1}$. MS $(\mathrm{CI} /$ isobutane $)=m / z, 701$ $\left((\mathrm{M}+\mathrm{H})^{+}\right)$.

4.4.4.2. (+)-(4R,5S,6S)-4,5,6,7-Tétrakis-benzyloxy-2methylene-heptanoic acid methyl ester 13 . Yield $=73 \%$ (colorless oil). $[\alpha]_{\mathrm{D}}^{25}=+6.2\left(c\right.$ 2.34, $\left.\mathrm{CHCl}_{3}\right) . R_{\mathrm{f}}=0.48$ (cyclohexane/ethyl acetate, 8:2). ${ }^{13} \mathrm{C}$ NMR $(100.61 \mathrm{MHz}$,
$\left.\mathrm{CDCl}_{3}\right) \delta: 176.5(\mathrm{C} 1) ; 135.8-135.3\left(\mathrm{C}_{i p s o}\right) ; 134.3(\mathrm{C} 8)$; 124.6 (C2); 75.7 (C5); 74.6 (C6); 73.9 (C4); 71.6/71.1/70.6/ $70.4\left(4 \times \mathrm{OCH}_{2}\right) ; 66.9(\mathrm{C} 7) ; 33.5(\mathrm{C} 3) ; 15.8\left(\mathrm{CH}_{3}\right.$ ester $)$. IR (neat) $2927(\mathrm{C}-\mathrm{H}) ; 1732(\mathrm{C}=\mathrm{O}) ; 1667(\mathrm{C}=\mathrm{C}) ; 1090(\mathrm{C}-$ O) $\mathrm{cm}^{-1}$. MS $(\mathrm{CI} /$ isobutane $)=m / z 581\left((\mathrm{M}+\mathrm{H})^{+}\right)$.

\section{References and notes}

1. Unger, F. M. Adv. Carbohydr. Chem. Biochem. 1981, 38, 323-388.

2. Reimer, L. M.; Conley, D. L.; Pompliano, D. L.; Frost, J. W. J. Am. Chem. Soc. 1986, 108, 8010. Draths, K. M.; Frost, J. W. J. Am. Chem. Soc. 1990, 112, 1657.

3. Le Maréchal, P.; Froussios, C.; Level, M.; Azerad, R. Carbohydr. Res. 1981, 94, 1.

4. (a) Ghalambor, M. A.; Levine, E. M.; Heath, E. C. J. Biol. Chem. 1966, 241, 3207-3215. (b) Frick, W.; Krülle, T.; Schmidt, R. R. Liebigs Ann. Chem. 1991, 435. (c) Burke, S. D. Org. Lett. 1999, 1, 71-74. (d) Adlersberg, M.; Sprinson, D. B. Carbohydr. Res. 1984, 127, 9. (e) Hermann, K. M.; Poling, M. D. J. Biol. Chem. 1975, 250, 6817. (f) Ramage, R.; MacLeod, A. M.; Rose, G. W. Tetrahedron 1991, 47, 5625. (g) Lopez-Herrera, F. P.; Sarabia-Garcia, F. Tetrahedron Lett. 1994, 36, 6705. (h) Barton, D. H. R.; Liu, W. Tetrahedron Lett. 1997, 38, 367. (i) Barton, D. H. R.; Liu, W. Tetrahedron Lett. 1997, 53, 12067.

5. (a) Sugai, T.; Shen, G.-J.; Ichikawa, Y.; Wong, C.-H. J. Am. Chem. Soc. 1993, 115, 413. (b) Augé, C.; Delest, V. Tetrahedron: Asymmetry 1995, 6, 863.

6. (a) Machajewski, T. D.; Wong, C.-H. Angew. Chem., Int. Ed. 2000, 39, 1352. (b) Kobori, Y.; Myles, D. C.; Whitesides, G. M. J. Org. Chem. 1992, 57, 5899-5907. (c) Wymer, N.; Toone, E. J. Curr. Opin. Chem. Biol. 2000, 4, 110. (d) Wong, C.-H.; Whitesides, G. M. J. Org. Chem. 1983, 48, 3199. (e) Effenberger, F.; Null, V. Liebigs Ann. Chem. 1992, 1211-1212. (f) Ziegler, T.; Straub, A.; Effenberger, F. Angew. Chem., Int. Ed. Engl. 1988, 27, 716-717. (g) Bolte, J.; Demuynck, C.; Samaki, H. Tetrahedron Lett. 1987, 28, $5525-5528$.

7. (a) Enoch, K.; Gordon, D. M.; Whitesides, W. G. J. Org. Chem. 1993, 58, 5500-5507. (b) Chan, T.-H.; Lee, M.-C. J. Org. Chem. 1995, 60, 4228-4232. (c) Prenner, R. H.; Schmid, W. Monatsh. Chem. 1996, 127, 1045-1050. (d) Martin, L. D.; Stille, J. K. J. Org. Chem. 1982, 47, $3630-3633$.

8. Guérard, C.; Demuynck, C.; Bolte, J. Tetrahedron Lett. 1999, 40, 4181-4182.

9. Crestia, D.; Guérard, C.; Veschambre, H.; Hecquet, L.; Demuynck, C.; Bolte, J. Tetrahedron: Asymmetry 2001, 12, 869.

10. Lipshutz, B. H.; Harvey, D. F. Synth. Commun. 1982, 12(4), 267.

11. Gefflaut, T.; Lemaire, M.; Valentin, M.-L.; Bolte, J. J. Org. Chem. 1997, 62, 5920.

12. Bernardski, M. D.; Waldmann, H. J.; Whitesides, G. M. Tetrahedron Lett. 1986, 27, 5807.

13. (a) Kobori, Y.; Myles, D. C.; Whitesides, G. M. J. Org. Chem. 1992, 57, 5899-5907. (b) Lindstad, R. I.; Koll, P.; MckinleyMckee, J. S. Biochem. J. 1998, 330, 479-487.

14. Stevens, R. V.; Beaulieu, N.; Chan, W. H.; Daniesky, T. T.; 
Waldner, A.; Williard, P. G.; Zutter, U. J. Am. Chem. Soc. 1986, 108, 1039.

15. (a) Chan, T.-H.; Li, C.-J. J. Chem. Soc., Chem. Commun. 1992, 10, 747. (b) Bloor, S. J. Tetrahedron Lett. 1993, 34, 5617. (c) Hon, Y.-S.; Lin, W.-C. Tetrahedron Lett. 1995, 36, 7693. (d) Steger, M.; Young, D. W. Tetrahedron 1999, 55,7935 .
16. Hecquet, L.; Demuynck, C.; Bolte, J. J. Mol. Catal. B: Enzym. 2001, 6, 797-802.

17. Bergmeyer, H. U.; 3rd ed. Methods of enzymatic analysis, Verlag Chemie: Deerfield, FL, 1984; Vol. 2, p 146.

18. Besse, P.; Baziard-Mouysset, G.; Boubekeur, K.; Palvadeau, P.; Veschambre, H.; Payard, M.; Mousset, G. Tetrahedron: Asymmetry 1999, 10, 4745-4754. 